\title{
Covid-19 management: it's inappropriate to make judgments in hindsight that rely on information not available at the outset
}

\author{
Andrew N Bamji retired consultant rheumatologist
}

Rye TN31 7ES, UK

Critics of covid-19 management say that something should have been done weeks before it was, ${ }^{1}$ forgetting that most aspects of the infection were unknown before January. If tests haven't been invented, you can't test; if unreliable, they are useless. If infection is asymptomatic then testing only those with symptoms will miss many. Why are death rates in different countries markedly different? Are countries with low case fatality rates testing more widely? Are there differences in virulence or population susceptibility? And what is the infection fatality rate (which is probably less alarming)? Why are the elderly more likely to die? Which comorbidities matter? Is the death of a young medical professional related to the quantity of virus exposure or something else? How many deaths attributed to covid-19 are from something else? Is immune paresis or a cytokine storm (or neither) the mechanism of severe consequences? Is a lockdown policy a greater or lesser risk to society than collapse of the economy?

At present we don't know. The retrospectoscope may provide answers. Yes, isolate the currently infected and those who are at risk of infection, but let those who have already been infected go back to work. A negative antigen test doesn't tell us whether the subject has never had covid-19 or has had it and recovered. Any antibody positive person can reconnect with the world now; how long immunity lasts is for future research. Start with health professionals; get the general population tested as fast as possible. Which is what will be done, as soon as the tests are available and reliable.

I don't agree with Helen Salisbury that scientific advice has been "extremely poor." ${ }^{2}$ It is impossible to advise on the unknown, and inappropriate to make judgments in hindsight that rely on information not available at the outset.

\section{Competing interests: None declared.}

Full response at: www.bmj.com/content/368/bmj.m1199/rr-5.

Godlee F. Covid-19: weathering the storm. Editor's choice. BMJ 2020;368:m119910.1136/bmj.m1199.

2 Salisbury H. Helen Salisbury: Coronavirus diaries. BMJ 2020;368:m1178. 10.1136/bmj.m1178 32209552

Published by the BMJ Publishing Group Limited. For permission to use (where not already granted under a licence) please go to http:/group.bmj.com/group/rights-licensing/ permissions 